\title{
PROFITABILITAS, UKURAN PERUSAHAAN, KINERJA LINGKUNGAN, PERTUMBUHAN PENJUALAN DAN LEVERAGE PADA PENGUNGKAPAN ISLAMIC CORPORATE SOCIAL REPORTING
}

\begin{abstract}
The purpose of this study is to examine the effect of profitability, company size, environmental performance, sales growth and leverage on the disclosure of Islamic Corporate Social Reporting. The population in this study are all companies listed on the Sharia Securities List during 2016-2018. The sample is determined by purposive sampling technique so that and data are analyzed using descriptive statistics and multiple linear regression analysis. Based on the partial test results show that profitability has no significant effect on the disclosure of Islamic Corporate Social Reporting (ICSR). Company size has no significant effect on the disclosure of Islamic Corporate Social Reporting (ICSR). The company's sales growth has no significant effect on the disclosure of Islamic Corporate Social Reporting (ICSR). The company's environmental performance has a significant effect on the disclosure of Islamic Corporate Social Reporting (ICSR) and leverage has a significant effect on the disclosure of Islamic Corporate Social Reporting (ICSR).
\end{abstract}

ABSTRAK: Tujuan dari penelitian ini adalah menguji pengaruh profitabilitas, ukuran perusahaan, kinerja lingkungan, Pertumbuhan Penjualan dan leverage terhadap pengungkapan Islamic Corporate Social Reporting. Populasi dalam penelitian ini adalah seluruh perusahaan yang terdaftar di Daftar Efek Syariah selama 2016-2018. Sampel ditentukan dengan tehnik purposive sampling sehingga dan Data dianalisis menggunakan statistik deskriptif dan analisis regresi linier berganda. Berdasarkan hasil uji secara parsial menunjukkan bahwa profitabilitas tidak berpengaruh signifikan terhadap pengungkapan Islamic Corporate Social Reporting (ICSR). Ukuran perusahaan tidak berpengaruh signifikan terhadap pengungkapan Islamic Corporate Social Reporting (ICSR). Pertumbuhan penjualan perusahaan tidak berpengaruh signifikan terhadap pengungkapan Islamic Corporate Social Reporting (ICSR). Kinerja lingkungan perusahaan berpengaruh signifikan terhadap pengungkapan Islamic Corporate Social Reporting (ICSR) dan Leverage berpengaruh signifikan terhadap pengungkapan Islamic Corporate Social Reporting (ICSR).

\author{
Vika Fitranita ${ }^{1}$, Indah \\ oktari Wijayanti ${ }^{2}$ \\ ${ }^{1,2}$ Fakultas Ekonomi dan Bisnis, \\ Universitas Bengkulu
}

Keyword: Profitability, Company Size,Environmental Performance, Sales Growth, Leverage, Disclosure of Islamic Corporate Social Reporting

Kata Kunci: profitabilitas, ukuran perusahaan, kinerja lingkungan, Pertumbuhan Penjualan, leverage terhadap pengungkapan Islamic Corporate Social Reporting 


\section{Pendahuluan}

Dalam Islam, suatu lembaga atau perusahaan hendaknya menjalankan bisnisnya sesuai dengan prinsip-prinsip syariah, namun selama ini pengukuran pengungkapan CSR pada perbankan syariah masih mengacu pada Global Reporting Initiative Index (Indeks GRI). Terkait dengan adanya kebutuhan mengenai pengungkapan tanggung jawab sosial di perbankan syariah, saat ini marak diperbincangkan mengenai Islamic Social Reporting Index (selanjutnya disebut indeks ISR) (Azhar dan Trisnawati, 2013). Indeks ISR berisi kompilasi item-item standar CSR yang ditetapkan oleh AAOIFI (Accounting and Auditing Organization for Islamic Financial Institutions) yang kemudian dikembangkan oleh para peneliti mengenai item-item CSR yang seharusnya diungkapkan oleh suatu entitas Islam (Fitria dan Hartanti, 2010). Indeks ISR diyakini dapat menjadi suatu langkah awal dalam hal penyusunan standar pengungkapan tanggung jawab sosial suatu entitas yang berbasis syariah.

Penerapan ISR pada perbankan syariah telah dilakukan oleh penelitian sebelumnya. Gray, Owen dan Adams (1996) dalam Paino (2001) menjelaskan bahwa pengungkapan informasi tanggung jawab dalam bank syariah dipengaruhi oleh dua faktor. Pertama,tingkat pengungkapan CSRpada bank syariah selalu berfokus pada lingkungan. Kedua, selalu berorientasi pada teori legitimasi dan upaya untuk menciptakan konsep relevan publics. Sedangkan Purwitasari (2011),melakukan penelitian pada bank Syariah Mandiri dan Muamalat Indonesia. Hasil pada peneliian ini menjelaskan tindakan pelaporan tanggung jawab sosial oleh BSM dan BMI masih dipengaruhi oleh kepentingan mereka masingmasing. Kepentingan-kepentingan ini terutama dipengaruhi oleh moneydan power.Sairally (2005) mengevaluasi pelaksanaan CSRpada 250 lembaga keuangan Islam berkesimpulan bahwa pada dasarnya pemahaman dan implikasi etika keuangan Islam bagi pengelola lembaga keuangan Islam harus dipraktekkan secara konsisten terutama dalam pelaksanaan CSR.

Akan tetapi menurut hasil kajian ternyata tingkah laku pengelola lembaga keuangan Islam tidak konsisten dengan teori yang berlaku. Indikasinya adalah dana yang sedikit untuk melaksanakan CSR. Alokasi dana yang minimum menunjukkan bahwa pelaksanaan CSRpada bank syariah rendah.Othman, Thani dan Ghani (2009),melakukan penelitian mengenai praktek pelaporan CSR perusahaan syariah yang listingdi bursa Malaysia, dan hasilnya memperlihatkan bahwa kebanyakan masih pada tahap konseptual. Hal ini dikarenakan belum adanya standar yang bisa di adopsi perusahaan dalam penerapan CSRsyariah tersebut.Sofyani,Ulum, Syam, Wahjuni (2012) melakukan penelitian Islamic Social Reporting Index Sebagai Model Pengukuran Kinerja Sosial Perbankan Syariah (Studi Komparasi Indonesia Dan Malaysia). Dan dari hasil penelitian ini, ditemukan beberapa bukti bahwa secara umum, perbankan syariah di Malaysia memiliki tingkatkinerja sosial yang lebih tinggi dibandingkan perbankan syariah yang ada di Indonesia. Kedua kinerja sosial perbankan syariah di Indonesia pada tahun 2010 mengalami kenaikan yang cukup signifikan, yakni sekitar $10 \%$ dari tahun sebelumnya yaitu tahun 2009 . Sedangkan tingkat kinerja sosial pada perbankan syariah di Malaysia bisa dikatakan stabil karena tidak mengalami kenaikan maupun penurunan. Ketiga semua bank syariah baik Indonesia maupun Malaysia, masih belum ada satupun yang mencapai angka penuh, yakni implementasi dan pengungkapan Indeks ISRsecara $100 \%$. Hal ini dikarenakan adanya sub item dari Indeks ISRyang memang tidak mungkin dipenuhi oleh industri perbankan seperti green product, audit environmental, dan bantuan untuk aktivitas politik.Penelitian selanjutnya mengenai Islamic Social Reporting Index dan kinerja sosial perusahaan (Corporate Social Responsibility) menjadi suatu hal yang penting untuk mendukung praktik tanggungjawab sosial dan syariah di Indonesia 
Berkembangnya ISR di Indonesia turut meningkatkan perhatian masyarakat terhadap lembaga atau institusi syariah. Maulida dkk (2014) menyatakan bahwa sangat disayangkan peneliti mengenai pelaksanaan ISR masih berorientasi di sektor perbankan syariah saja, sedangkan untuk sektor non erbankan dan lembaga keuangan lainnya seperti pasar modal, penelitian mengenai ISR belum banyak dilakukan sehingga kurang meluasnya konsep ISR terutama di Indonesia. Mengukur kinerja perusahaan yang notabene adalah profit motif dapat digunakan analisis profitabilitas.Profitability analysis yang implementasinya adalah profitability ratio disebut juga operating ratio, ada dua tipe ratio yakni margin on sale dan return on asset. Return On Asset(ROA) memfokuskankemampuan perusahaan untuk memperoleh earning dalam operasi perusahaan. Menurut ketentuan Bank Indonesia, standar yang paling baik untuk Return Onasset dalam ukuran lembaga keuangan Indonesia yaitu $1,5 \%$. Mengkaji tingkat profitabilitas dari lembaga keuangan berarti mengkaji perlunya suatu informasi lebih lanjut sebagai faktor penyebab yang mempengaruhi besarnya nilai ROA.

Peningkatan kinerja keuangan lembaga keuangan syariah ini menjadi menarik untuk diteliti karena hal ini mengindikasikan bahwa kinerja keuangan lembaga keuangan syariah sama baiknya dengan kinerja keuangan dari lembaga keuangan konvensional. Keterkaitan antara kinerja keuangan perusahaan dengan pengungkapan ICSR terkait dengan teori legitimasi yang dikemukakan oleh para ahli, bahwasannya legitimasi dari sebuah perusahaan merupakan sebuah siklus yang kompleks, dimana kinerja keuangan yang baik dari perusahaan akan meningkatkan legitimasi perusahaan tersebut (Dowling dan Pfeffer 1975, dalam Arifin, dkk, 2012).

Peningkatan kinerja keuangan yang diperlihatkan oleh lembaga keuangan syariah menjadi dasar ketertarikan penelitian ini, dimana kondisi tersebut memperlihatkan bahwa kinerja lembaga keuangan syariah pada saat ini memiliki perkembangan yang sama baiknya dengan perkembangan kinerja keuangan lembaga keuangan konvensional. Peneliti merasa tertarik untuk melakukan kajian secara mendalam terkait tingkat pengungkapan CSR lembaga keuangan syariah di Indonesia dan faktor kinerja keuangan yang merupakan salah satu faktor yang dapat mempengaruhi tingkat pengungkapan CSR tersebut.

\section{Pengembangan Hipotesis}

Konsep Corporate Responsibility(CSR) dalam Perspektif Islam, Praktik CSR dalam Islam menekankan pada etika bisnis islami. Operasional perusahaan harus terbebas dari berbagai modus praktik korupsi dan memberi jaminan layanan maksimal sepanjang operasionalnya, termasuk layanan terpercaya bagi setiap produknya (provision and development of safe and reliable products). Hal ini yang secara tegas tercantum dalam Al-Quran. Allah SWT berfirman: ".... Maka sempurnakanlah takaran dan timbangan dan janganlah kamu kurangkan bagi manusia barang-barang takaran dan timbangannya,....'(QS. al-A'raf ayat 85).

Islamic Corporate Social Responsibility (ICSR) merupakan sebuah konsep CSR yang menekankan pada pendekatan kerohanian sebagai dasar dari kewajiban perusahaan untuk memiliki tanggung jawab sosial kepada lingkungan sekitarnya, baik lingkungan alam maupun masyarakat (Norajilah: 2011).

Pengungkapan Islamic Corporate Social Responsibility (ICSR), Pengungkapan ICSR oleh lembaga syariah berbeda dengan konsep pengungkapan CSR lembaga konvensional lainnya, demikian juga konsep pengungkapan dalam lembaga keuangan syariah. Konsep pengungkapan ICSR yang dilakukan oleh lembaga keuangan syariah harus mencakup seluruh kegiatan yang ditujukan kepada objek ICSR yaitu alam, direct stakeholder, dan indirect stakeholder.

Indeks ISR berisi kompilasi item-item standar CSR yang ditetapkan oleh AAOIFI (Accounting and Auditing Organization for Islamic Financial Institutions) yang kemudian dikembangkan oleh para peneliti mengenai itemitem CSR yang seharusnya di ungkapkan oleh 
suatu entitas Islam (Fitria dan Hartanti, 2010). Ada enam tema pengungkapan dalam indeks ISR yaitu, investasi dan keuangan, produk dan jasa, tenaga kerja, sosial, lingkungan dan tata kelola perusahaan.

\section{HIPOTESIS}

\section{Keterkaitan Return on Assets terhadap Tingkat Pengungkapan ICSR}

Profitabilitas merupakan kemampuan dari perusahaan untuk memperoleh laba, sementara ROA merupakan tingkat kemampulabaan perusahaan dengan memanfaatkan seluruh aset yang dimiliki oleh perusahaan tersebut. Hal ini mengindikasikan bahwa peningkatan profitabilitas perusahaan akan menyebabkan terjadinya peningkatan pengungkapan ICSR.

\section{H1 : Return on Asset berpengaruh secara positif dan signifikan terhadap Tingkat Pengungkapan ICSR}

\section{Keterkaitan Ukuran Perusahaan terhadap Tingkat Pengungkapan ICSR}

Menurut (Kasmir, 2015) investor selalu mempertimbangkan kemampuan operasional perusahaan yang tercermin pada total aset dari perusahaan itu sendiri, dan karenanya perusahaan dengan total aset yang besar dinilai memiliki kemampuan operasional yang juga besar sehingga akan memiliki aktivitas yang lebih besar dengan kemampuan laba yang juga lebih besar.Teori legitimasi mengasumsikan adanya kontrak sosial antara sebuah institusi dengan lingkungan sosial di sekitarnya (Arifin, dkk: 2012), karenanya sebuah perusahaan dengan ukuran yang semakin besar akan selalu berusaha memberikan manfaat yang lebih besar kepada masyarakat dan menyampaikannya melalui pengungkapan dalam laporan keberlanjutan. Hal ini berarti semakin besar ukuran sebuah perusahaan maka akan semakin tinggi tingkat pengungkapan CSR dari perusahaan tersebut.

H2 :Ukuran Perusahaan berpengaruh secara positif dan signifikan terhadap Tingkat Pengungkapan ICSR

\section{Keterkaitan Pertumbuhan Penjualan terhadap Tingkat Pengungkapan ICSR}

Menurut Swastha (2000), pertumbuhan atas penjualan merupakan indikator penting dari penerimaan pasar dari produk dan/atau jasa perusahaan tersebut, dimana pendapatan yang dihasilkan dari penjualan akan dapat digunakan untuk mengukur tingkat pertumbuhanpenjualan. Pada teori keagenan, dinyatakan bahwa manajer bertindak sebagai agen yang harus dapat memenuhi keinginan dari para pemilik modal, termasuk didalamnya kebutuhan informasi keuangan perusahaan.Hal ini menggambarkan bahwa semakin tinggi pertumbuhan penjualan sebuah perusahaan maka akan semakin tinggi tingkat pengungkapan ISR dari perusahaan tersebut. Pertumbuhan perusahaan (growth) dapat menunjukkan peningkatan kinerja keuangan perusahaan. Maria Ulfa (2009) menyatakan bahwa growth merupakan tingkat pertumbuhan perusahaan yang diukur dengan pertumbuhan penjualan perusahaan. Pertumbuhan perusahaan merupakan salah satu pertimbangan para investor dalam menanamkan investasinya. Perusahaan yang memiliki kesempatan tumbuh yang tinggi diharapkan akan memberikan profitabilitas yang tinggi di masa depan, diharapkan laba lebih persisten, sehingga investor akan tertarik untuk berinvestasi di perusahaan tersebut.

H3 : Pertumbuhan Penjualan berpengaruh secara positif dan signifikan terhadap Tingkat Pengungkapan ICSR

\section{Pengaruh Kinerja Lingkungan terhadap Pengungkapan ICSR}

Indeks ISR yang kelima membahas tentang tema lingkungan. Perusahaan dengan kinerja lingkungan yang baik, akan cenderung mengungkapkan performance perusahaan dalam tanggung jawab sosialnya yang berkaitan dengan tema lingkungan dalam indeks ISR. Hasil penelitian Maulida dkk (2014) serta Rahmawati dan Achmad (2012) menunjukkan adanya pengaruh antara kinerja lingkungan dengan pengungkapan ISR, sedangkan penelitian Wijaya (2012), dan Oktalia (2014) menyatakan bahwa kinerja lingkungan memiliki pengaruh yang tidak 
signifikan terhadap pengungkapan tanggung jawab sosial. Oleh karena itu, rumusan hipotesis dalam penelitian ini adalah:

\section{H4 : Kinerja lingkungan berpengaruh terhadap Tingkat Pengungkapan ICSR.}

\section{Pengaruh Leverage terhadap Pengungkapan ICSR}

Menurut Stice, Stice, dan Skousen (2009) rasio leverage adalah suatu indikasi yang menggambarkan sejauh mana perusahaan menggunakan dana pihak luar untuk membeli aset. Perusahaan yang mempunyai tingkat leverage yang rendah tentunya akan menarik minat investor dalam menanamkan modalnya, karena mereka tidak khawatir akan kemampuan perusahaan dalam menyelesaikan kewajibannya. Hasil pengujian yang dilakukan oleh Firmansyah dan Hariyanto (2014) serta Rizkiningsih (2012) menunjukkan adanya pengaruh antara leverage dengan pengungkapan ISR. Lain halnya dengan Kariza (2015), dan Dewi (2012) yang hasil penelitiannya menunjukkan bahwa leverage tidak berpengaruh terhadap pengungkapan ISR. Berdasarkan penjelasan diatas, maka dapat dirumusakan hipotesis sebagai berikut:

H5 : Leverage berpengaruh terhadap Tingkat Pengungkapan ICSR

\section{POPULANSI DAN SAMPEL}

Populasi dalam penelitian ini adalah perusahaan yang terdaftar di Daftar Efek Syariah selama tiga periode di tahun 2016 sampai dengan 2018. Sampel dalam penelitian ditentukan dengan tehnik purposive sampling, dengan kriteria. Kriteria pemilihan sampel adalah sebagai berikut:

1. Perusahaan yang terdaftar di BEI pada tahun 2016-2018.

2. Perusahaan yang menggunakan Rupiah sebagai mata uang fungsionalnya.

3. Perusahaan yang mempublikasikan annual report tahun 2016 dan tersedia untuk publik.

\section{Operasionalisasi variabel \\ Variabel Dependen}

Variabel dependen pada penelitian ini adalah tingkat pengungkapan tanggung jawab sosial perusahaan yang diukur dengan indeks ICSR. Indeks ICSR dalam penelitian ini merupakan indeks dari penelitian Raditya (2012). Penilaian indeks ISR dilakukan dengan menggunakan penilaian dari nilai $0-1$, dimana :

- Nilai 0 jika tidak ada pengungkapan terkait item tersebut.

- Nilai 1 jika ada pengungkapan terkait item tersebut.

Apabila seluruh item telah diungkapkan maka nilai maksimal yang dapat dicapai adalah sebesar 46. Perhitungan indeks pengungkapan ISR dirumuskan sebagai berikut:

Disclosure Level: Jumlah skor disclosure yang dipenuhi X 100\%

Jumlah skor maksimum

\section{Variabel Independen}

1. Profitabilitas

Profitabilitas adalah suatu kemampuan perusahaan dalam menghasilkan keuntungan atau laba. Profitabilitas merupakan kemampuan dari perusahaan untuk memperoleh laba, sementara ROA merupakan tingkat kemampulabaan perusahaan dengan memanfaatkan seluruh aset yang dimiliki oleh perusahaan tersebut.

$$
\text { ROA: } \frac{\text { Net Income x } 100 \%}{\text { Total Assets }}
$$

\section{Ukuran Perusahaan}

Ukuran perusahaan yang dimaksud adalah besar kecilnya perusahaan yang diukur dengan total aset perusahaan. Untuk menyamakan bentuk variabel data total aset dengan variabel data lainnya, maka total aset akan dibentuk menjadi logaritma natural (ln).

Ukuran Perusahaan $=$ Ln (total asset) 


\section{Pertumbuhan Penjualan}

Pertumbuhan Penjualan adalah perbandingan dari perubahan (kenaikan ataupun penurunan) dalam jumlah total penjualan pada aktiva akhir tahun terhadap awal tahun. Pertumbuhan Penjualan dinyatakan dalam satuan persentase

Pertumbuhan Penjualan $=\underline{\text { Penjualan }(\mathrm{t})-}$ Penjualan(t-1) X $100 \%$

Penjualan (t-1)

\section{Kinerja Lingkungan}

Kinerja lingkungan adalah kinerja perusahaan dalam menciptakan lingkungan yang baik (green). Pengukuran kinerja lingkungan dalam penelitian ini dengan melihat prestasi perusahaan dalam mengikuti PROPER yang dilakukan oleh Kementrian Lingkungan Hidup. Sistem peringkat kinerja PROPER mencakup pemeringkatan perusahaan dalam 5 (lima) warna, yakni:

- $\quad$ Emas : Sangat Sangat Baik; skor $=5$

- Hijau : Sangat Baik; skor $=4$

- Biru : Baik; skor = 3

- Merah : Buruk; skor $=2$

- Hitam : Sangat Buruk; skor $=14.3$

\section{Leverage}

Leverage menggambarkan sampai sejauh mana aktiva suatu perusahaan dibiayai oleh hutang. DER merupakan hasil bagi antara total hutang dengan total ekuitas.

DER $\frac{\text { : Total Liabilities }}{\text { Total Shareholder's Equity }} \times 100 \%$

\section{Hasil Analisis Data}

Analisis yang dilakukan dalam penelitian ini meliputi analisis terhadap variabel dependen yaitu Islamic Social Reporting yang diukur dengan menggunakan metode content analysis dengan cara membaca dan menganalisis laporan keuangan tahunan perusahaan serta analisis terhadap variabel independen yaitu profitabilitas (ROA), ukuran perusahaan (PP), kinerja lingkungan (KL), Pertumbuhan penjualan (PP), dan Leverage (DER) Pada penelitian ini menggunakan sampel 43 perusahaan yang listing di Jakarta Islamic Index. Teknik yang digunakan dalam penelitian ini yaitu teknik purposive sampling dengan pertimbangan (judgment sampling) jumlah sampel sebanyak 43 perusahaan. Pengolahan Variabel dalam penelitian ini menggunakan program SPSS versi 25.

Tabel 5.1

Hasil Penentuan Sampel

\begin{tabular}{|l|c|}
\hline \multicolumn{1}{|c|}{ Kriteria } & \multicolumn{1}{|c|}{$\begin{array}{c}\text { Jumlah } \\
\text { Perusahaan }\end{array}$} \\
\hline $\begin{array}{l}\text { Perusahaan yang listing di } \\
\text { Indeks Saham Syariah } \\
\text { Indonesia }\end{array}$ & 331 \\
\hline $\begin{array}{l}\text { Perusahaan yang tidak } \\
\text { sesuai Kriteria }\end{array}$ & $(288)$ \\
\hline Jumlah Sampel & 43 \\
\hline $\begin{array}{l}\text { Total Sampel penelitian } \\
\text { untuk 3 Tahun (2016-2018) }\end{array}$ & 129 \\
\hline
\end{tabular}

Sumber : Data penelitian Diolah, 2019

\section{Deskripsi Islamic Social Corporate Reporting}

ISR adalah standar pelaporan kinerja sosial perusahaan-perusahaan yang berbasis syariah. ISR merupakan tolak ukur pelaksanaan kinerja social yang berisi kompilasi berisi kompilasi item-item standar CSR yang ditetapkan oleh AAOIFI (Accounting and Auditing Organization for Islamic Financial Institutions) yang kemudian dikembangkan oleh para peneliti mengenai item-item CSR yang seharusnya di ungkapkan oleh suatu entitas Islam (Fitria dan Hartanti, 2010).

Indeks ISR adalah item-item pengungkapan yang digunakan sebagai indikator dalam pelaporan kinerja sosial institusi bisnis Syariah. Secara khusus indeks ini adalah perluasan dari standar pelaporan kinerja sosial yang meliputi harapan masyarakat tidak hanya mengenai peran perusahaan dalam perekonomian, tetapi juga peran perusahaan dalam perspektif spiritual. Selain itu indeks ini juga menekankan pada keadilan sosial terkait mengenai lingkungan, hak minoritas, dan karyawan (Fitria dan Hartati, 2010). Ada enam tema pengungkapan 
dalam indeks ISR yaitu, investasi dan keuangan, produk dan jasa, tenaga kerja, sosial, lingkungan dan tata kelola perusahaan.

Hasil perhitungan Indeks Islamic Social Reporting berikut:

\begin{tabular}{|c|c|c|c|c|c|}
\hline \multirow{2}{*}{$\begin{array}{l}\mathbf{N} \\
\mathbf{0}\end{array}$} & \multirow[b]{2}{*}{$\begin{array}{c}\text { Perusahaa } \\
\text { n }\end{array}$} & \multicolumn{4}{|c|}{$\begin{array}{c}\text { Persentase Indeks } \\
\text { Pengungkapan } \\
\text { Corporate Governance } \\
\end{array}$} \\
\hline & & $\begin{array}{c}201 \\
2\end{array}$ & $\begin{array}{c}201 \\
3\end{array}$ & $\begin{array}{c}201 \\
4\end{array}$ & $\begin{array}{c}\text { Rata- } \\
\text { rata/ } \\
\text { perusaha } \\
\text { an }\end{array}$ \\
\hline 1. & AALI & 0.57 & 0.59 & 0.59 & 0.58 \\
\hline 2. & ADMG & 0.54 & 0.57 & 0.57 & 0.56 \\
\hline 3. & ADRO & 0.61 & 0.63 & 0.63 & 0.62 \\
\hline 4. & AMFG & 0.37 & 0.41 & 0.41 & 0.40 \\
\hline 5. & ANJT & 0.54 & 0.57 & 0.57 & 0.56 \\
\hline & ANTM & 0.70 & 0.70 & 0.72 & 0.70 \\
\hline & ASII & 0.65 & 0.65 & 0.65 & 0.65 \\
\hline & AUTO & 0.59 & 0.59 & 0.59 & 0.59 \\
\hline & BEST & 0.43 & 0.48 & 0.48 & 0.46 \\
\hline 10. & BSSR & 0.46 & 0.48 & 0.48 & 0.47 \\
\hline 11. & BYAN & 0.50 & 0.50 & 0.50 & 0.50 \\
\hline 12 & CAMP & 0.37 & 0.41 & 0.41 & 0.40 \\
\hline 13 & CTBN & 0.43 & 0.43 & 0.48 & 0.45 \\
\hline 14 & ICBP & 0.52 & 0.52 & 0.54 & 0.53 \\
\hline 15 & INCO & 0.50 & 0.52 & 0.52 & 0.51 \\
\hline 16 & INRU & 0.39 & 0.39 & 0.41 & 0.40 \\
\hline 17 & INTP & 0.54 & 0.59 & 0.59 & 0.57 \\
\hline & IPOL & 0.48 & 0.50 & 0.50 & 0.49 \\
\hline 19 & ISSP & 0.52 & 0.52 & 0.54 & 0.53 \\
\hline 20 & ITMG & 0.37 & 0.37 & 0.41 & 0.38 \\
\hline 21 & JPFA & 0.50 & 0.50 & 0.52 & 0.51 \\
\hline 22 & KAEF & 0.65 & 0.67 & 0.67 & 0.67 \\
\hline 23 & KIAS & 0.37 & 0.41 & 0.41 & 0.40 \\
\hline 24 & KINO & 0.46 & 0.48 & 0.50 & 0.48 \\
\hline 25 & KLBF & 0.52 & 0.52 & 0.54 & 0.53 \\
\hline 26 & KMTR & 0.50 & 0.50 & 0.54 & 0.51 \\
\hline 27 & KRAS & 0.50 & 0.52 & 0.54 & 0.52 \\
\hline 28 & LSIP & 0.54 & 0.54 & 0.54 & 0.54 \\
\hline 29 & NIKL & 0.43 & 0.43 & 0.48 & 0.45 \\
\hline 30 & PALM & 0.46 & 0.46 & 0.48 & 0.46 \\
\hline 31 & SGRO & 0.50 & 0.50 & 0.52 & 0.51 \\
\hline 32 & SIDO & 0.46 & 0.50 & 0.50 & 0.49 \\
\hline 33 & SIMP & 0.46 & 0.46 & 0.48 & 0.46 \\
\hline
\end{tabular}

\begin{tabular}{|c|c|c|c|c|}
\hline 34 SMBR & 0.54 & 0.54 & 0.57 & 0.55 \\
\hline \begin{tabular}{|l|l|}
35 & SMCB \\
\end{tabular} & 0.50 & 0.50 & 0.52 & 0.51 \\
\hline \begin{tabular}{|l|l|}
36 & SMGR \\
\end{tabular} & 0.63 & 0.67 & 0.67 & 0.66 \\
\hline 37 SMMT & 0.43 & 0.46 & 0.46 & 0.45 \\
\hline \begin{tabular}{|l|l|}
38 & SPMA \\
\end{tabular} & 0.37 & 0.37 & 0.41 & 0.38 \\
\hline \begin{tabular}{|l|l|}
39 & SRSN \\
\end{tabular} & 0.24 & 0.24 & 0.33 & 0.27 \\
\hline \begin{tabular}{|l|l|}
40 & TINS \\
\end{tabular} & 0.63 & 0.63 & 0.65 & 0.64 \\
\hline \begin{tabular}{|l|l|}
41 & TOTO \\
\end{tabular} & 0.46 & 0.43 & 0.46 & 0.45 \\
\hline \begin{tabular}{|l|l|}
42 & TPIA \\
\end{tabular} & 0.43 & 0.43 & 0.48 & 0.45 \\
\hline \begin{tabular}{|l|l|}
43 & UNTR \\
\end{tabular} & 0.57 & 0.57 & 0.57 & 0.57 \\
\hline Mean/Th & 0.44 & 0.45 & 0.47 & 0,57119 \\
\hline Minimum & \multicolumn{4}{|l|}{0.27} \\
\hline Maximum & \multicolumn{4}{|l|}{0.70} \\
\hline Standar deviasi & \multicolumn{4}{|c|}{0.176206188} \\
\hline
\end{tabular}

Sumber: Data sekunder yang diolah tahun 2019

Persentase indeks pengungkapan didapatkan dari jumlah nilai setiap pengungkapan yang didapatkan perusahaan dibagi dengan total dari jumlah keseluruhan indeks pengungkapan yaitu 46 point. Dari data keseluruhan sampel, perusahaan yang mendapatkan nilai terendah adalah PT. Indo Acidatama Tbk (SRSN) dengan nilai persentase 0.24 pada tahun 2016. Hal ini dikarenakan perusahaan tidak mengungkapkan secara luas pengungkapan didalam laporan keuangan tahunan perusaahan. Pada pengungkapan social reporting perusahaan hanya memperoleh nilai 11 yaitu sebesar $24 \%$ dari total jumlah penilaian seluruh penilaian indeks social reporting sebesar 46 point. Sementara itu untuk nilai persentase indeks social reporting yang tertinggi dimiliki oleh PT. Aneka Tambang, Tbk (ANTM) dengan nilai pengungkapan 0.72 atau dengan setara $72 \%$ pada tahun 2018 .

\section{Uji Statistik Deskriptif}

Berdasarkan hasil analisis deskriptif statistik, maka berikut di dalam tabel 5.3 ditampilkan karakteristik sampel yang digunakan di dalam penelitian ini meliputi: jumlah sampel $(\mathrm{N})$, nilai minimum, nilai maksimum, rata-rata sampel (mean), serta standar deviasi untuk masing-masing variabel.

\section{Tabel 5.3}




\begin{tabular}{|l|c|r|r|r|r|}
\multicolumn{7}{|c|}{ Hasil Statistik Deskriptif } \\
\hline & Descriptive Statistics \\
\hline & $\mathrm{N}$ & $\begin{array}{c}\text { Minim } \\
\text { um }\end{array}$ & $\begin{array}{c}\text { Max } \\
\text { imu } \\
\mathrm{m}\end{array}$ & Mean & $\begin{array}{c}\text { Std. } \\
\text { Deviati } \\
\text { on }\end{array}$ \\
\hline ROA & 129 & .0012 & 3.40 & .7950 & .59351 \\
\hline UP & 129 & 2.98 & 32.3 & 19.30 & 11.458 \\
& & & 9 & 64 & 85 \\
\hline PP & 129 & -.50 & 2.30 & .1524 & .34890 \\
\hline KL & 129 & 3.00 & 5.00 & 3.403 & .52320 \\
& 129 & .08 & 7.67 & .9750 & 1.2151 \\
\hline DER & 129 & & & & \\
\hline $\begin{array}{l}\text { Valid N } \\
\text { (listwise) }\end{array}$ & 129 & & & & \\
\hline
\end{tabular}

1. Profitabilitas

Profitabilitas merupakan kemampuan dari perusahaan untuk memperoleh laba dan merupakan factor yang membuat manajemen menjadi bebas dan fleksibel untuk mengungkapkan pertanggungjawaban sosial kepada pemegang saham. Rasio Profitabilitas mengukur kemampuan para eksekutif dalam menciptakan tingkat keuntungan. Profitabilitas menunjukkan seberapa besar kinerja keuangan perusahaan dalam menghasilkan keuntungan. Tabel 5.3 menunjukkan nilai rasio profitabilitas yang diukur dengan ROA diperoleh nilai ROA terendah 0,0012 , Nilai tertinggi 3,4, nilai rata-rata 0,7950 dan nilai standard deviation sebesar 0,59351 .

\section{Ukuran Perusahaan}

Sebuah perusahaan dengan ukuran yang semakin besar akan selalu berusaha memberikan manfaat yang lebih besar kepada masyarakat dan menyampaikannya melalui pengungkapan dalam laporan keberlanjutan, melakukan aktivitas yang lebih banyak, menyebabkan dampak yang lebih besar terhadap lingkungan dan semakin besar ukuran perusahaan biasanya informasi yang tersedia untuk investor dalam pengambilan keputusan terkait dengan investasi dalam perusahaan tersebut semakin banyak. Tabel 5.3 menunjukkan nilai ukuran perusahaan yang diukur diperoleh nilai ukuran perusahaan terendah 2,98, Nilai tertinggi 32,39 , nilai rata-rata 19,3064 dan nilai standard deviation sebesar 11,45885.

3. Pertumbuhan Penjualan

Pertumbuhan perusahaan (growth) dapat menunjukkan peningkatan kinerja keuangan perusahaan. Maria Ulfa (2009) menyatakan bahwa growth merupakan tingkat pertumbuhan perusahaan yang diukur dengan pertumbuhan penjualan perusahaan. Pertumbuhan perusahaan merupakan salah satu pertimbangan para investor dalam menanamkan investasinya. Perushaan dengan pertumbuhan yang tinggi akan mendapat banyak sorotan sehingga diprediksi perusahaan yang mempunyai kesempatan pertumbuhan yang lebih tinggi cenderung lebih banyak melakukan tanggung jawab soal perusahaannya sehingga dianggap bahwa dapat memperluas pengungkapan Islamic corporate social repoting (ICSR) nya. Tabel 5.3 menunjukkan nilai pertumbuhan penjualan perusahaan yang diukur diperoleh nilai pertumbuhan penjualan perusahaan terendah $-0,50$, Nilai tertinggi 2,30, nilai rata-rata 0,1524 dan nilai standard deviation sebesar 0,34890 .

\section{Kinerja Lingkungan}

Kinerja lingkungan adalah kinerja perusahaan dalam menciptakan lingkungan yang baik (green). Pengukuran kinerja lingkungan dalam penelitian ini dengan melihat prestasi perusahaan dalam mengikuti PROPER yang dilakukan oleh Kementerian Lingkungan Hidup. kinerja lingkungan dapat menggambarkan suatu perusahaan memiliki perilaku peduli lingkungan atau tidak, dimana perusahaan dengan kinerja lingkungan yang tinggi 
akan mendapatkan nilai positif dalam pandangan masyarakat dan investor. Tabel 5.3 menunjukkan nilai kinerja lingkungan perusahaan yang diukur diperoleh nilai kinerja lingkungan yang terendah 3 yaitu predikat Biru dengan nilai Baik, dan Nilai tertinggi adalah 5 yang mendapatkan predikat Emas dengan nilai sangat sangat baik, nilai rata-rata 3,4031 dan nilai standard deviation sebesar 0,52320

\section{Leverage}

Leverage digunakan untuk mengukur kemampuan perusahaan dalam memenuhi seluruh kewajibannya kepada pihak lain. Rasio leverage menggambarkan sampai sejauh mana aktiva suatu perusahaan dibiayai oleh hutang.Leverage digunakan untuk mengukur kemampuan perusahaan dalam memenuhi seluruh kewajibannya kepada pihak lain. Rasio leverage menggambarkan sampai sejauh mana aktiva suatu perusahaan dibiayai oleh hutang. Manajemen dengan tingkat leverage yang tinggi akan mengurangi pengungkapan sosialnya demi menghindari pemeriksaan kreditur (Swastiningrum, 2013). Tabel 5.3 menunjukkan nilai Leverage yang diukur dengan DER memperoleh nilai terendah yaitu 0,008 dan Nilai tertinggi adalah 7,67, nilai rata-rata 0,9750 dan nilai standard deviation sebesar 1,21510.

\section{Uji Asumsi Klasik}

Penelitian yang menggunakan model regresi linier berganda harus memenuhi pengujian uji asumsi klasik. Uji asumsi klasik dilakukan untuk menentukan ketepatan model agar hasil penelitian tidak bias. Uji asumsi klasik yang digunakan dalam penelitian ini adalah sebagai berikut:

\section{Uji Normalitas}

Uji normalitas bertujuan untuk menguji apakah dalam model regresi, variabel pengganggu atau residual memiliki distribusi normal (Ghozali, 2011). Untuk menghindari bias, data yang digunakan harus terdistribusi normal. Persamaan regresi dinyatakan baik jika mempunyai data variabel bebas dan data variabel terikat berdistribusi mendekati normal atau normal sama sekali (Sunyoto, 2009).

Uji normalitas dalam penelitian ini dilakukan dengan menggunakan uji Kolmogorov-Smirnov dengan melihat angka signifikan > 0,05 yang berarti bahwa data terdistribuasi normal. Namun sebaliknya, jika nilai probabilitasnya $<0,05$ maka data tidak terdistribusi normal.

\section{Tabel 5.4}

Uji Normalitas

One-Sample Kolmogorov-Smirnov Test

Unstandardiz

ed Residual

\begin{tabular}{llr}
\hline $\mathrm{N}$ & & 129 \\
\hline Normal & Mean & .0000000 \\
\cline { 2 - 3 } Parameters $^{\mathrm{a}, \mathrm{b}}$ & Std. & .08230124 \\
& Deviation & \\
\hline Most Extreme & Absolute & .063 \\
\cline { 2 - 3 } Differences & Positive & .063 \\
\cline { 2 - 3 } & Negative & -.045 \\
\hline Test Statistic & & .063 \\
\hline Asymp. Sig. (2-tailed) & $.200^{\mathrm{c}, \mathrm{d}}$ \\
\hline
\end{tabular}

a. Test distribution is Normal.

b. Calculated from data.

c. Lilliefors Significance Correction.

d. This is a lower bound of the true significance.

Sumber: Data output spss yang diolah tahun 2019

Berdasarkan hasil pengujian normalitas menunjukkan bahwa taraf signifikansi adalah sebesar 0,200>0,05. Dengan demikian nilai residual terdistribusi secara normal, sehingga model penelitian ini dinyatakan telah memenuhi syarat normalitas.

\section{Uji Multikolinieritas}

Uji multikolinieritas bertujuan untuk menguji apakah model regresi ditemukan adanya korelasi antar variabel bebas (independen) (Ghozali, 2011). Model regresi yang baik seharusnya tidak terjadi korelasi di antara variabel independen. Uji multikolinieritas dilakukan dengan melihat 
nilai tolerance dan nilai Variance Inflation Factor (VIF). Nilai cutoff yang umum dipakai untuk menunjukkan adanya multikolinieritas adalah nilai tolerance $<0,10$ atau sama dengan nilai VIF > 10 (Ghozali, 2011). Hasil pengujian untuk masing-masing variabel adalah sebagai

\section{Model Summary ${ }^{b}$}

\begin{tabular}{|l|c|c|c|r|r|}
\hline $\begin{array}{l}\text { Mod } \\
\mathrm{el}\end{array}$ & $\mathrm{R}$ & $\begin{array}{c}\text { Squa } \\
\mathrm{r}\end{array}$ & $\begin{array}{c}\text { Adjust } \\
\text { ed R } \\
\text { Squar } \\
\mathrm{e}\end{array}$ & $\begin{array}{c}\text { Std. Error of } \\
\text { the Estimate }\end{array}$ & $\begin{array}{c}\text { Durbin- } \\
\text { Watson }\end{array}$ \\
\hline 1 & \begin{tabular}{rl|r}
.56 \\
$5^{\mathrm{a}}$
\end{tabular} & .320 & .310 & 0.14023 & 1.815 \\
\hline
\end{tabular}

berikut :

Uji Multikolinieritas dengan Nilai Tolerance dan VIF

\begin{tabular}{|c|c|c|c|}
\hline \multirow[t]{2}{*}{$\begin{array}{c}\text { Variab } \\
\text { el }\end{array}$} & \multicolumn{2}{|c|}{$\begin{array}{rl}\text { Collinearit } & \text { Statistik } \\
y & s \\
\end{array}$} & \multirow[t]{2}{*}{ Keterangan } \\
\hline & Tolerance & VIF & \\
\hline ROA & 0,947 & 1,056 & $\begin{array}{l}\text { Tidak terjadi } \\
\text { multikolinearit } \\
\text { as }\end{array}$ \\
\hline UP & 0,980 & 1,020 & $\begin{array}{l}\text { Tidak terjadi } \\
\text { multikolinearit } \\
\text { as }\end{array}$ \\
\hline PP & 0,972 & 1,029 & $\begin{array}{l}\text { Tidak terjadi } \\
\text { multikolinearit } \\
\text { as }\end{array}$ \\
\hline $\mathrm{KL}$ & 0,938 & 1.066 & $\begin{array}{l}\text { Tidak terjadi } \\
\text { multikolinearit } \\
\text { as }\end{array}$ \\
\hline DER & 0,999 & 1.001 & $\begin{array}{l}\text { Tidak terjadi } \\
\text { multikolinearit } \\
\text { as }\end{array}$ \\
\hline
\end{tabular}

Sumber: Data sekunder yang diolah tahun 2019

Dilihat dari tabel diatas, semua nilai tolerance > 0,10 dan nilai $V I F<10$. Hal ini menunjukkan bahwa dalam model regresi tidak terdapat korelasi antara variabel independen atau tidak terjadi multikolinieritas.

\section{Uji Autokorelasi}

Uji autokorelasi bertujuan menguji apakah dalam model regresi ada korelasi antara kesalahan pengganggu pada periode $t$ dengan kesalahan pengganggu pada periode $t-1$ (sebelumnya) (Ghozali, 2011). Jika terjadi korelasi, maka hal itu mengindikasikan adanya masalah autokorelasi. Autokorelasi muncul karena observasi yang berurutan sepanjang waktu berkaitan satu sama lainnya. Model regresi yang baik adalah model regresi yang terbebas dari masalah autokorelasi. Pengambilan keputusan tidak terjadinya autokorelasi adalah $\mathrm{du}<\mathrm{dw}<4-\mathrm{du}$. Hasil pengujian autokorelasi adalah sebagai berikut.

\section{Uji Autokorelasi (Durbin-Watson Test)}

Sumber: Data sekunder yang diolah tahun 2019

Berdasarkan tabel signifikansi 5\% dengan jumlah sampel 129 dan jumlah variabel independen $5(\mathrm{k}=5)$, maka tabel Durbin-Watson memperlihatkan nilai $d u=1,7937$. Nilai $d w=1,815$ lebih besar dari nilai $d u=1,7937$ dan lebih kecil dari $4-d u(4-1,7937)=2,2063$. Maka dalam model regresi ini tidak terjadi autokorelasi positif maupun negatif yang disimpulkan dari nilai $d u<d w<(4-d u)$, yaitu $1,7937<1,815<2,2063$

\section{Uji Heterokedastisitas}

Uji heteroskedastisitas bertujuan menguji apakah dalam model regresi terjadi ketidaksamaan variance dari residual satu

\section{Model Summary ${ }^{b}$}

\begin{tabular}{|l|l|r|r|r|r|}
\hline $\begin{array}{l}\text { Mod } \\
\mathrm{el}\end{array}$ & $\mathrm{R}$ & $\begin{array}{c}\mathrm{R} \\
\text { Square }\end{array}$ & $\begin{array}{c}\text { Std. } \\
\text { Adjusted } \\
\text { R Square }\end{array}$ & $\begin{array}{c}\text { Error of } \\
\text { the } \\
\text { Estimate }\end{array}$ & $\begin{array}{l}\text { Durbin- } \\
\text { Watson }\end{array}$ \\
\hline 1 & $.565^{\mathrm{a}}$ & .320 & .310 & 0.14023 & 1.815 \\
\hline
\end{tabular}

pengamatan yang lain (Ghozali, 2011). Jika variance dari residual satu pengamatan ke pengamatan lain tetap, maka disebut homoskedastisitas dan jika berbeda disebut heteroskedastisitas. Model regresi yang baik adalah yang terjadi homokedastisitas bukan heteroskedastisitas. Untuk mendeteksi ada tidaknya heteroskedastisitas, dilakukan dengan melihat grafik plot antara nilai prediksi variabel 


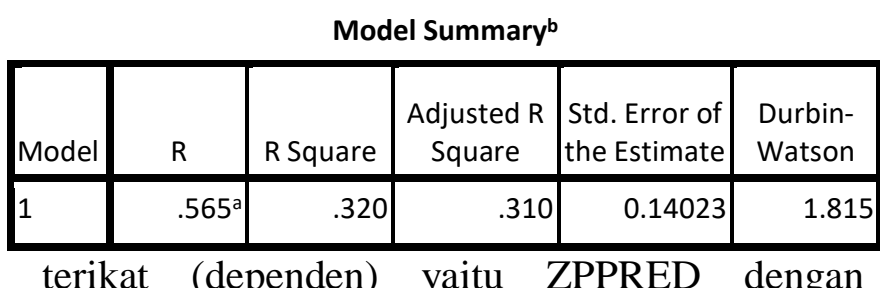

residualnya SRESID. Deteksi ada tidaknya heteroskedatisitas dapat dilakukan dengan melihat pola tertentu pada grafik scatterplot antara ZPRED dan SRESID. Hasil pengujian heterokedastisitas dapat dilihat dari gambar 4.1 berikut ini:

\section{Uji Heterokedastisitas dengan Scatterplot}

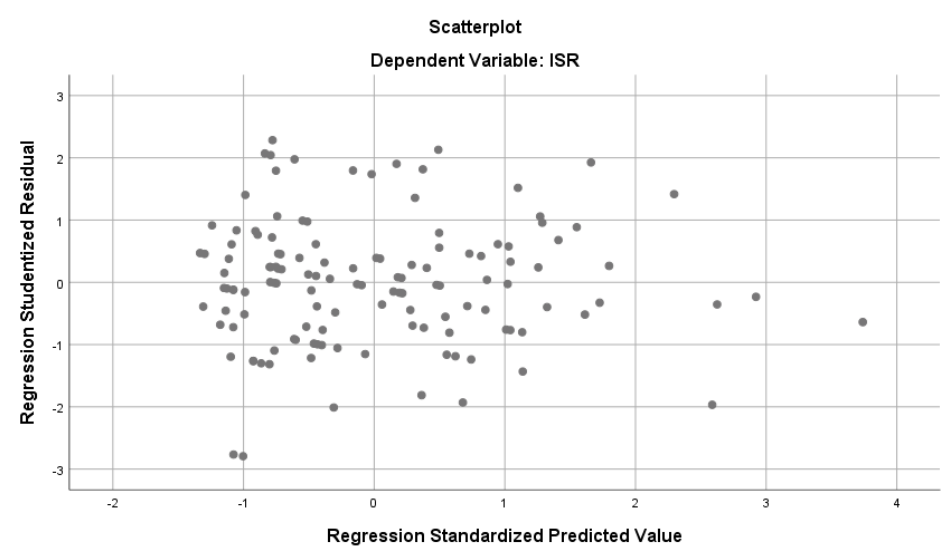

Sumber: Data sekunder yang diolah, tahun 2019

Titik-titik yang ada pada gambar 4.1 diatas tidak memiliki pola tertentu yang jelas, titik-titik pada grafik sccaterplot menyebar di atas dan di bawah angka 0 pada sumbu Y. dari pola tersebut dapat disimpulkan bahwa tidak terjadi heteroskedatisitas pada model regresi yang digunakan, sehingga model regresi layak untuk Digunakan Untuk Memprediksi Indeks Social Repoting Berdasarkan Variabel Independen Yaitu Profitabilitas, Ukuran Perusahaan, Kinerja Lingkungan, Pertumbuhan Penjualan Dan Leverage.

\section{Koefisien Determinasi (R Square)}

Koefisien determinasi $\left(\mathrm{R}^{2}\right)$ pada intinya mengukur seberapa jauh kemampuan model dalam menerangkan variasi variabel dependen. Nilai $\mathrm{R}^{2}$ yang kecil berarti kemampuan variabel independen dalam menjelaskan variasi variabel dependen amat terbatas. Nilai yang mendekati satu berarti variabel independen memberikan hampir semua informasi yang dibutuhkan untuk memprediksi variasi variabel dependen (Ghozali, 2011). Berikut ini adalah hasil perhitungan koefisien determinasi:

\section{Koefisien Determinasi}

Sumber: Data sekunder yang diolah tahun 2019

Tabel di atas memperlihatkan nilai $\mathrm{R}^{2}$ ( $R$ square) sebesar 0,320 atau $32 \%$. Hal ini menunjukkan bahwa kemampuan variabel independen yaitu Profitabilitas, Ukuran Perusahaan, Kinerja Lingkungan, Pertumbuhan Penjualan Dan Leverage dalam menjelaskan variasi variabel dependen yaitu Indeks social reporting adalah sebesar 32\% sedangkan sisanya sebesar 68\% $(100 \%$ - 32\%) dijelaskan oleh variabel lain di luar model penelitian.

\section{Pengaruh Profitabilitas, Ukuran Perusahaan, Kinerja Lingkungan, Pertumbuhan Penjualan Dan Leverage Secara Parsial Terhadap Indeks social reporting}

Pengujian secara parsial pada dasarnya digunakan untuk mengetahui pengaruh masingmasing variabel independen yaitu mekanisme corporate governance (Profitabilitas, Ukuran Perusahaan, Kinerja Lingkungan, Pertumbuhan Penjualan Dan Leverage) terhadap variabel dependen yaitu Indeks social reporting. Untuk menginterpretasikan koefisien variabel independen (bebas) dapat menggunakan hasil analisis regresi seperti tersaji pada tabel 4.13 di bawah ini.

\section{Uji Signifikansi Secara Parsial (Uji t)}

\begin{tabular}{|c|c|c|c|c|c|}
\hline \multicolumn{6}{|c|}{ Coefficients $^{\mathrm{a}}$} \\
\hline \multirow[b]{2}{*}{ Model } & $\begin{array}{r}\text { Unst } \\
\mathrm{i} \\
\text { Coef }\end{array}$ & $\begin{array}{l}\text { andard } \\
\text { ed } \\
\text { ficient } \\
\text { s }\end{array}$ & $\begin{array}{c}\text { Standardi } \\
\text { zed } \\
\text { Coefficie } \\
\text { nts }\end{array}$ & & \\
\hline & B & $\begin{array}{l}\text { Std. } \\
\text { Error }\end{array}$ & Beta & $\mathrm{t}$ & Sig. \\
\hline $\begin{array}{l}1 \text { (Consta } \\
n t)\end{array}$ & $\begin{array}{r}.34 \\
1 \\
\end{array}$ & .055 & & $\begin{array}{r}6.19 \\
2\end{array}$ & .000 \\
\hline
\end{tabular}




\begin{tabular}{|l|r|r|r|r|r|}
\hline ROA & - & .013 & -.026 & -.304 & .762 \\
& .00 & & & & \\
\hline UP & 4 & & & & \\
& .00 & .001 & -.111 & - & .189 \\
& 1 & & & 1.32 & \\
\hline PP & .02 & .022 & .085 & 1.00 & .316 \\
& 2 & & & 7 & \\
\hline KL & .05 & .015 & .293 & 3.40 & .001 \\
& 0 & & & 8 & \\
\hline DER & .01 & .006 & .174 & 2.09 & .038 \\
& 3 & & & 6 & \\
\hline
\end{tabular}

a. Dependent Variable: ISR

Sumber: Output SPSS, Coefficients

Variabel dependen pada model regresi ini adalah Indeks social reporting, sedangkan variabel independen adalah Profitabilitas, Ukuran Perusahaan, Kinerja Lingkungan, Pertumbuhan Penjualan Dan Leverage. Model regresi berdasarkan hasil analisis tabel 4.13 adalah:

$$
\begin{aligned}
\text { ISR }= & 0.341-0.004 \text { ROA }-0.001 \mathrm{UP}+0.022 \\
& \text { PP }+0.050 \mathrm{KL}+0.013 \mathrm{DER}+\varepsilon
\end{aligned}
$$

Penjelasan dari persamaan diatas adalah sebagai berikut.

1. Nilai konstanta sebesar 0.341 menyatakan bahwa jika ada Profitabilitas, Ukuran Perusahaan, Kinerja Lingkungan, Pertumbuhan Penjualan Dan Leverage maka kemungkinan besarnya nilai indeks social repoting adalah 0.341 .

2. Koefisien regresi ROA sebesar $-0,004$ menyatakan bahwa jika ROA mengalami peningkatan sebesar 1 maka tidak akan diikuti kenaikan pengungkapan ISR sebesar 0,004 dengan asumsi nilai koefisien variable independent lainnya konstan atau sama dengan nol.

3. Nilai koefisisen regresi variable ukuran perusahaan (UP) sebesar -0.001 menyatakan bahwa Ukuran perusahaan mengalami peningkatan sebesar 1 maka tidak akan diikuti kenaikan pengungkapan ISR sebesa 0,001 dengan asumsi nilai variable independent lainnya konstan atau sama dengan nol.
4. Koefisien regresi pertumbuhan penjualan (PP) sebesar 0,022 yang bertanda positif menunjukkan bahwa, apabila nilai pertumbuhan penjualan meningkat maka akan meningkatkan ISR sebesar 2,2\%

5. Koefisien persamaan regresi kinerja lingkungan bernilai positif sebesar 0,050 berarti bahwa peningkatan kinerja lingkungan sebesar nilai satuan maka akan terjadi peningkatan pengungkapan Islamic Social Reporting sebesar 0,050 dengan asumsi variable bebas lainnya konstan.

6. Koefisien regresi leverage adalah sebesar 0,013 yang bertanda positif menunjukkan bahwa, apabila nilai pertumbuhan penjualan meningkat maka akan meningkatkan ISR sebesar 1,3\%

\section{Pengaruh Profitabilitas terhadap Tingkat Pengungkapan ISR}

Profitabilitas merupakan kemampuan dari perusahaan untuk memperoleh laba dan merupakan factor yang membuat manajemen menjadi bebas dan fleksibel untuk mengungkapkan pertanggungjawaban sosial kepada pemegang saham. Berdasarkan tabel 5.8, nilai signifikansi (Sig) variabel Profitabilitas lebih besar dari nilai $\alpha$ yaitu 0,762>0,05 Hasil perhitungan menunjukkan bahwa profitabilitas tidak berpengaruh signifikan terhadap pengungkapan Islamic Social Reporting secara parsial sehingga dapat disimpulkan bahwa hipotesis pertama (H1) ditolak. Hal ini mengindikasikan bahwa perusahaan yang mempunyai tingkat profitabilitas yang tinggi belum tentu banyak melakukan aktivitas sosial karena perusahaan lebih berorientasi pada laba semata. Sedangkan pada saat perusahaan memperoleh laba yang rendah, maka terdapat persepsi bahwa pengguna laporan keuangan senang untuk membaca berita baik tentang kinerja perusahaan dalam bidang social. Hasil penelitan ini sejalan dengan Penelitian (Muhammad Fajrul Novrizal, (2016)) 


\section{Pengaruh Ukuran Perusahaan terhadap Tingkat Pengungkapan ISR}

Sebuah perusahaan dengan ukuran yang semakin besar akan selalu berusaha memberikan manfaat yang lebih besar kepada masyarakat dan menyampaikannya melalui pengungkapan dalam laporan keberlanjutan. Perusahaan besar merupakan emiten yang banyak disoroti sehingga pengungkapan tanggung jawab sosialnya akan lebih besar untuk pengurangan biaya politis sebagai wujud tanggung jawab sosial perusahaan.

Berdasarkan tabel 5.8, nilai signifikansi (Sig) variabel Ukuran Perusahaan lebih besar dari nilai $\alpha$ yaitu $0,180>0,05$ Hasil perhitungan menunjukkan bahwa ukuran perusahaan tidak berpengaruh signifikan terhadap pengungkapan Islamic Social Reporting secara parsial sehingga dapat disimpulkan bahwa hipotesis pertama $(\mathrm{H} 2)$ ditolak. Tidak adanya pengaruh yang signifikan ini mengindikasikan bahwa tinggi rendahnya ukuran perusahaan atau Size maka tidak berpengaruh penting pada pengungkapan ISR. Hasil penelitian ini mengindikasikan bahwa Perusahaan yang terdaftar pada Daftar Efek Syariah yang berukuran besar belum tentu mengungkapkan informasi berbasis Islam yang lebih luas dibandingkan perusahaan pada Daftar efek Syariah yang berukuran kecil. Hasil penelitian ini sejalan dengan Penelitian (Ardiani Ika sulistyawati, 2017).

\section{Pengaruh Pertumbuhan Penjualan terhadap Tingkat Pengungkapan ISR}

Pertumbuhan perusahaan (growth) dapat menunjukkan peningkatan kinerja keuangan perusahaan. Maria Ulfa (2009) menyatakan bahwa growth merupakan tingkat pertumbuhan perusahaan yang diukur dengan pertumbuhan penjualan perusahaan. Pertumbuhan perusahaan merupakan salah satu pertimbangan para investor dalam menanamkan investasinya.

Berdasarkan tabel 5.8, nilai signifikansi (Sig) variabel pertumbuhan penjualan lebih besar dari nilai $\alpha$ yaitu $0,316>0,05$ Hasil perhitungan menunjukkan bahwa pertumbuhan penjualan perusahaan tidak berpengaruh signifikan terhadap pengungkapan Islamic Social Reporting secara parsial sehingga dapat disimpulkan bahwa hipotesis pertama (H3) ditolak. Hal ini mengindikasikan bahwa inggi rendahanya pertumbuhan perusahaan tidak mempengaruhi tingkat pengungkapan Islamic Social Reporting (ISR) hal ini disebabkan bahwa semua investor belum menyadari sepenuhnya pentingnya Islamic Social Reporting (ISR) dan pada umumnya perusahaan melalukan pengungkapan Islamic Social Reporting (ISR) hanya sebagai bagian dari iklan dan menghindari untuk tidak memberikan informasi yang tidak relevan. Kebanyakan investor berorientasi pada kinerja jangka pendek kepada keuntungan (profit) pada tahun berjalan, sedangkan Islamic Social Reporting (ISR) dianggap berpengaruh pada kinerja jangka menengah dan jangka Panjang.

\section{Pengaruh Kinerja Lingkungan terhadap Tingkat Pengungkapan ISR}

Kinerja lingkungan adalah kinerja perusahaan dalam menciptakan lingkungan yang baik (green). Pengukuran kinerja lingkungan dalam penelitian ini dengan melihat prestasi perusahaan dalam mengikuti PROPER yang dilakukan oleh Kementerian Lingkungan Hidup. Kinerja lingkungan hidup merupakan mekanisme perusahaan secara sukarela mengintegrasikan perhatiannya terhadap lingkungan ke dalam operasi dan interaksinya dengan stakeholders yang melebihi tanggung jawab organisasi.

Berdasarkan tabel 5.8, nilai signifikansi (Sig) variabel kinerja lingkungan lebih kecil dari nilai $\alpha$ yaitu $0,001<0,05$ Hasil perhitungan menunjukkan bahwa kinerja lingkungan perusahaan berpengaruh signifikan terhadap pengungkapan Islamic Social Reporting secara parsial sehingga dapat disimpulkan bahwa hipotesis keeempat $(\mathrm{H} 4)$ diterima. Penelitian ini menemukan haisl yang menandakan bahwa kinerja lingkungan yang telah dilakukan perusahaan memberikan pengaruh yang besar bagi perusahaan untuk melakukan pengungkapan tanggung jawab sosialnya dalam hal ini oengungkapan terkait Islamic Corporate Social Repoting. Bahwasannya baik dan buruknya kinerja lingkungan yang dilakukan perusahaan berpengaruh terhadap pengungkapan Islamic Social Reporting atau tanggunng jawab sosialnya. 
Jadi semakin baik kinerja lingkungan yang dilakukan oleh suatu perusahaan meningkatkan tingkat pengungkapan yang dilakukan oleh perusahaan tersebut. Hasil penelitian ini tidak sejalan dengan penelitian (Eka Hartawati, 2017) yang menyatakan bahwa kinerja lingkungan yang telah dilakukan perusahaan tidak memberikan pengaruh yang cukup besar bagi perusahaan untuk melakukan pengungkapan tanggung jawab sosialnya.

\section{Pengaruh Leverage terhadap Tingkat Pengungkapan ISR}

Leverage digunakan untuk mengukur kemampuan perusahaan dalam memenuhi seluruh kewajibannya kepada pihak lain. Rasio leverage menggambarkan sampai sejauh mana aktiva suatu perusahaan dibiayai oleh hutang.Leverage digunakan untuk mengukur kemampuan perusahaan dalam memenuhi seluruh kewajibannya kepada pihak lain. Rasio leverage menggambarkan sampai sejauh mana aktiva suatu perusahaan dibiayai oleh hutang. Manajemen dengan tingkat leverage yang tinggi akan mengurangi pengungkapan sosialnya demi menghindari pemeriksaan kreditur (Swastiningrum, 2013).

Berdasarkan tabel 4.13, nilai signifikansi (Sig) variabel leverage lebih besar dari nilai $\alpha$ yaitu 2,956>0,05 Hasil perhitungan menunjukkan bahwa leverage berpengaruh signifikan terhadap pengungkapan Islamic Social Reporting secara parsial sehingga dapat disimpulkan bahwa hipotesis kelima (H5) ditolak. Hal ini mengindikasikan bahwa tidak adanya pengaruh yang signifikan ini mengindikasikan bahwa tinggi rendahnya hutang perusahaan yang diperoleh perusahaan dilihat dari rasio leverage tidak berdampak pada pengungkapan ISR. Hal ini sejalan dengan penelitian yang telah dilakukan oleh Kariza (2015), dan Dewi (2012) yang hasil penelitiannya menunjukkan bahwa leverage tidak berpengaruh terhadap pengungkapan ISR.

\section{Kesimpulan dan Saran}

Berdasarkan hasil uji secara parsial yang menganalisis pengaruh Profitabilitas, ukuran perusahaan, kinerja lingkungan, Pertumbuhan
Penjualan dan leverage terhadap pengungkapan Islamic Corporate Social Reporting (ICSR) pada perusahaan yang terdaftar di Indeks Saham Syariah Indonesia (ISSI) tahun 2016-2018. maka dapat ditarik beberapa kesimpulan yaitu :

a. Nilai signifikansi variabel Profitabilitas sebesar 0,762 lebih besar dari nilai $\alpha$ yaitu $0,762>0,05$ Hasil perhitungan menunjukkan bahwa profitabilitas tidak berpengaruh signifikan terhadap pengungkapan Islamic Corporate Social Reporting (ICSR).

b. Nilai signifikansi (Sig) variabel Ukuran Perusahaan yaitu sebesar 0,180 lebih besar dari nilai $\alpha$ yaitu $0,180>0,05$ Hasil perhitungan menunjukkan bahwa ukuran perusahaan tidak berpengaruh signifikan terhadap pengungkapan Islamic Corporate Social Reporting (ICSR).

c. Nilai signifikansi (Sig) variabel pertumbuhan penjualan lebih besar dari nilai $\alpha$ yaitu $0,316>0,05$ Hasil perhitungan menunjukkan bahwa pertumbuhan penjualan perusahaan tidak berpengaruh signifikan terhadap pengungkapan Islamic Corporate Social Reporting (ICSR).

d. Nilai signifikansi (Sig) variabel kinerja lingkungan yaitu 0,001 lebih kecil dari nilai $\alpha$ yaitu $0,001<0,05$ Hasil perhitungan menunjukkan bahwa kinerja lingkungan perusahaan berpengaruh signifikan terhadap pengungkapan Islamic Corporate Social Reporting (ICSR)

e. Nilai signifikansi (Sig) variabel leverage yaitu sebesar 2,956 lebih besar dari nilai $\alpha$ yaitu 2,956>0,05 Hasil perhitungan menunjukkan bahwa leverage berpengaruh signifikan terhadap pengungkapan Islamic Corporate Social Reporting (ICSR).

Berdasarkan kesimpulan dan keterbatasan dalam penelitian ini, maka dapat dijadikan sebagai acuan untuk memberikan saran guna meningkatkan kualifikasi penelitian selanjutnya. Adapun saran yang dapat diberikan oleh penulis adalah sebagai berikut:

1. Bagi penelitian selanjutnya, sebaiknya : 
a. Menambah komponen yang tertera di variable dependent, dengan cara menambahkan komponen yang ada selain komponen yang sudah digunakan agar hasilnya dapat menggambarkan kondisi pengungkapan Islamic Corporate Social Reporting (ICSR) pada perusahaan yang listing di Jakarta Islamic Index (JII) yang masuk dalam perhitungan Indeks Saham Syariah (ISSI) pada Bursa Efek Indonesia.

b. Memperluas objek penelitian, dengan cara menambah sampel penelitian tidak hanya yang listing di Jakarta Islamic Index (JII) yang masuk dalam perhitungan Indeks Saham Syariah (ISSI) pada Bursa Efek Indonesia saja.

c. Memperpanjang atau menambahkan tahun sampel pengamatan, dengan cara memilih sampel yang sekiranya bisa representatif dalam menjelaskan kondisi pengungkapan Islamic Corporate Social Reporting (ICSR) perusahaan.

2. Bagi para akademisi, sebaiknya menyediakan berbagai sumber yang diperlukan dalam penelitian, sehingga penelitian selanjutnya menjadi lebih baik.

\section{DAFTAR PUSTAKA}

Astuti, Tri Puji. 2014. Faktor-Faktor yang Mempengaruhi Islamic Social Reporting (ISR) pada Bank Syariah. Naskah Publikasi. Fakultas Ekonomi dan Bisnis. Universitas Muhammadiyah Surakarta.

Ardiani Ika sulistyawati, I. Y. (2017). Pengungkapan Islamic Social Reporting pada Indeks Saham Syariah Indonesia. Journal of Accounting \& Finance, 13 No.2, 15-27.

Azhar, Fahri Ali dan Rina Trisnawati. 2013. Pengungkapam Islamic Social Reporting pada Bank Syariah di Indonesia. Proceeding Seminar Nasional dan Call for Papers Sancall. Universitas Muhammadiyah Surakarta.

Dewi, Indah Fitri K. 2012. Analisis Pengaruh Profitabilitas, Leverage, Likuiditas, Ukuran Perusahaan, dan Porsi Kepemilikan Publik atas Saham terhadap Pengungkapan Islamic Social Reporting pada Perusahaan Jakarta Islamic Index. Skripsi. Fakultas Ekonomi. Universitas Indonesia.

Eka Hartawati, N. L. (2017). Pengaruh Ukuran Perusahaan, Profitabilitas, kinerja sosial, Kinerja Lingkungan dan Komite Audit terhadap Pengungkapan Islamic Social Reporting (ISR) Pada Perusahaan yang Terdaftar di Jakarta Islamic Index (JII) periode Tahun 2014-2016. e-journal S1 AK, 8 No. 2.

findrambinina, R. (2011). Is Company Intelectual capital linked to corporate social responsibilities disclousure. IBIMA Publishing, 1-11.

Firmasnsyah, Irman dan Eko Hariyanto. 2014. Analisis Pengungkapan Kinerja Sosial (Social Disclosure) Perbankan Syariah di Indonesia dan Malaysia dalam Perspektif Islamic Social Reporting. Buletin Ekonomi Vol.12 No.1, halaman 69-84. 
Fitria, Soraya dan Dwi Hartanti. 2010. Islam dan Tangung Jawab Sosial : Studi Perbandingan Pengungkapan Berdasarkan Global Reporting Initiative Indeks dan Islamic Social Reporting Indeks. Makalah Simposium Nasional Akuntansi XIII. Purwokerto.

Ghozali, Imam. 2012. Aplikasi Analisis Multivariate dengan Program IBM SPSS 19. Edisi 5. Semarang : Badan Penerbit Universitas Diponegoro.

Ghozali, Imam dan Chariri. 2007. Teori Akuntansi. Semarang : Badan Penerbit Universitas Diponegoro.

Hanafi, M. Mamduh dan Abdul Halim. 2014. Analisis Laporan Keuangan. Edisi ke 4. UPP STIM YKPN. Yogyakarta.

Hardiyanti, Sari. 2012. Ananlisis Hubunan Shari'a Governance Structure terhadap Tingkat Pengungkapan Corporate Social Responsibility pada Perbankan Syariah di Indonesia. Skripsi. Fakultas Ekonomi. Universitas Indonesia.

Haryani, R. (2015). Analisis Pengaruh Dewan Pengawas Syariah dan Intelektual capital terhadap CSR. Semarang: skripsi Fakultas Ekonomi dan Bisnis.

Hermawan. (2014). Pengaruh Kinerja Keuangan terhadap nilai perusahaan dengan pengungkapan tanggung jawab sosial perusahaan. Jurnal Dinamika Akuntansi vol 3 No.2, 103-118.

Hong, P. T. (2007). Intellectual Capital and Financial Return of Companies. Journal of Intellectual Capital.Vol 3, No.1, 51-61.

Kariza, Ayu. 2015. Faktor-Faktor yang Mempengaruhi Pengungkapan Inslamic Social Reporting pada Perusahaan yang Listing di Jakarta Islamic Index. Skripsi. Palembang : Universitas Bina Darma.
Kementrian Lingkungan Hidup. 2014. Keputusan Nomor 180 tahun 2014 tentang Hasil Penilaian Peringkat Perusahaan Dalam Pengelolaan Lingkungan Hidup Tahun 2013-2014. http://proper.menlh.go.id

Maulida, Adelhita Purnasanti; Agung Yulianto dan Asrori. 2014. Analisis Faktor-Faktor yang Mempengaruhi Pengungkapan Islamic Social Reporting (ISR). Makalah Simposium Nasinal Akuntansi XVII. Mataram.

Muhammad Fajrul Novrizal, M. F. ((2016)). Faktor-Faktor yang mempengaruhi Pengukapan Corporate Social Responsibility (CSR) Pada perusahaan yang terdaftar di Jakarta Islamic Index (JII) tahun 2012-2015 dengan menggunakan ISR Index sebagai tolak ukur. Jurnal Ilmiah Mahasiswa Ekonomi Akuntansi (JIMEKA), Vol.1, No. 2, 177189.

Ningrum, Ratna Aditya; Fachrurrozzie dan Prabowo Yudo Jayanto. 2013. Pengaruh Kinerja Keuangan, Kepemilikan Institusional dan Ukuran Dewan Pengawas Syariah terhadap Pengungkapan ISR. Accounting Analysis Journal. Volume 2 Nomor 4.

Oktalia, Dwi. 2014. Pengaruh Kinerja Lingkungan dan Profitabilitas terhadap Corporate Social Responsibility Disclosure dalam laporan Tahunan Perusahaan. Artikel. Fakultas Ekonomi. Universitas Negeri Padang.

Otoritas Jasa Keuangan. 2014. Keputusan Dewan Komisioner Nomor: Kep-24/D.04/2014 Tanggal 20 Mei 2014. www.ojk.go.id

Otoritas Jasa Keuangan. 2014. Keputusan Dewan Komisioner Nomor: Kep-55/D.04/2014 Tanggal 21 November 2014. www.ojk.go.id

Raditya, Amilia Nurul. 2012. Analisis FaktorFaktor yang Mempengaruhi Tingkat Pengungkapan Islamic Social Reporting (ISR) pada Perusahaan yang Masuk Daftar Efek 
Syariah (DES). Skripsi. Fakultas Ekonomi. Universitas Indonesia.

Rahmawati, 'Ala dan Achmad Tarmizi. 2012. Pengaruh Kinerja Lingkungan terhadap Corporate Financial Performance dengan Corporate Social Responsibility Disclosure sebagai Variabel Intervening. Diponegoro Journal of Accounting. Volume 1 Nomor 2, Halaman 1-5.

Rizkiningsih, Priyesta. 2012. Faktor-Faktor yang Mempengaruhi Pengungkapan Islamic Social Reporting (ISR) : Studi Empiris pada Bank Syariah di Indonesia, Malaysia dan Negara Gulf Cooperation Council. Skripsi. Fakultas Ekonomi. Universitas Indonesia.

Stice, D James, Stice Earl K, dan K Fred Skousen. 2009. Akuntansi Keuangan Menengah (Intermediate Accounting). Buku 2 Edisi 16. Penerbit : Salemba Empat.

Widarjono, Agus. 2010. Analisis Statistika Multivariat Terapan. Yogyakarta: UPP STIM YKPN

Widiawati, Septi dan Surya Raharja. 2012. Analisis Faktor-Faktor yang Mempengaruhi Islamic Social Reporting PerusahaanPerusahaan yang Terdapat pada Daftar Efek Syariah Tahun 2009-2011. Diponegoro Journal of Accounting. Volume 1 Nomor 2. Halaman $1-15$

Wijaya, Maria. 2012. Faktor-Faktor yang Mempengaruhi Pengungkapan Tanggung Jawab Sosial pada Perusahaan Manufaktur yang Terdaftar di Bursa Efek Indonesia. Jurnal Ilmiah Mahasiswa Akuntansi. Volume 1 Nomor 
Journal Accounting and Finance

Edisi Vol. 4 No. 1 Maret 2020

Universitas Telkom 